This text has been published as:

Laura Junka-Aikio (2019) “Institutionalization, neo-politicization and the politics of defining Sámi research", Acta Borealia, 36:1, 1-22.

Archived final draft

\title{
Institutionalization, neo-politicization and the politics of defining Sámi research
}

Laura Junka-Aikio

Department of Cultural Sciences, Tromsø University Museum, UiT - Arctic University of Norway Tromsø, Norway

\begin{abstract}
This article critically examines recent changes in the social terrain of Sámi research in Finland, where the research field is subject to a new wave of academic institutionalization, and where questions regarding "Sáminess" have become particularly prominent. The article argues that in this conjuncture of institutionalization and neo-politicization, definitions of Sámi research which emphasize its political and ethical qualities ("Sámi research" as research done from a "Sámi perspective" or "taking it into account") appear increasingly problematic and can actually end up doing the opposite of what was originally intended. Instead of bringing questions regarding the politics of perspective, location, representation and power/knowledge to the fore, presenting the research field in these terms might turn attention away from a variety of interests and political desires that currently are projected onto Sámi research, and hence depoliticize understandings of Sámi research and its complex interdependence with the state and society.
\end{abstract}

\section{Introduction}

In the 1970s, the social terrain of research relating to the Sámi was radically transformed. Earlier "Lappologist" approaches seemed increasingly out-dated and colonial, and calls for (new) Sámi research, which would be accountable to Sámi societies' own needs and world- views rather than to those pertaining to the state and the dominant society, became pertinent. Sámi movements saw access to academic institutions and knowledge production as central for Sámi self-determination, and also the broader paradigm change towards critical perspectives within academia supported this shift, and its early institutionalization in the form of the Sámi Instituhtta, which was established in Guovdageaidnu in 1973.

Since then, university degrees, programmes, academic positions and entire institutions associated with this "post-Lappologist" turn in Sámi studies have been established across the Nordic states, and interest is still growing. For instance, in Finland, a number of universities and academic institutions now seem to compete over tasks and responsibilities relating to Sámi and Arctic Indigenous research, in part encouraged by new funding conditions set up by the state.

Although on-going efforts to direct new resources to Sámi research are welcome, my aim here is to examine some of the challenges that the field of research is facing in the present, focusing on developments in Finland. In particular, I seek to draw attention to the ways in which asymmetric power relations between Sámi and dominant societies continue to structure research relating to the Sámi, even when the stated aim of institutions involved in developing Sámi research is to undo such relations. I write this article as a "bordering actor" (Otnes 2006): as a Finnish scholar who holds long-term interest in questions of colonialism, and whose perspective on Sámi politics and research owes much to experience and expertise shared by a Sámi husband and in-laws. In addition to Indigenous and postcolonial perspectives on the politics of knowledge, the analysis is indebted to Stuart Hall, who stresses how academic institutionalization is always also a sign of much broader societal, political and economic changes, and hence worthy of critical study in its own right (Hall 1992). Why, I ask, is Sámi research receiving so much institutional attention in Finland, and why right now? What does the on-going boom tell about broader changes in the relationships between the Sámi, the state and the dominant society? And how do these changes impact upon the politics of defining Sami research, or upon strategies available for Sámi research as a critical field committed to Indigenous self-determination? I will address these questions by exploring the economic, social and political forces behind the current conjuncture, which is conceptualized here in terms of institutionialization and neo-politicization. Despite the focus on Finland, many parts of the discussion are bound to be relevant also in other parts of Sápmi, and for Indigenous research more broadly.

\section{Sámi research and its others}


Instead of referring to any research relating to Sámi people, the rise and scope of "Sámi research" as a field of its own is usually understood in terms of its difference from previous "Lappologist" research on the Sámi (Hirvonen 1999, 31-40; Lehtola 2005a, 2005b; Länsman 2008; Mustonen 2012; Seurujärvi-Kari 2012, 57-60; Mattson 2014; Nyyssönen and Lehtola 2017). In these contexts, Lappology is a catch-all term for research which was conducted on the Sámi by non-Sámi researchers in the context of modern nineteenth and twentieth century science, and mostly in the interests of the state and the dominant society, rather than of the Sámi themselves. Lehtola, who also cautions against homogenizing all research associated with Lappology as simply exploitative (Lehtola 2012, 184-185, 2017), notes that the general spirit of the time exposed the Sámi largely as an exotic and racialized object of outsider curiosity, and encouraged the dominant society to see the Sámi as a vanishing people, whose culture had to be documented for the purposes of historical and academic curiosity before it would pass over (Lehtola 2005b, 87). Lappologist research served the binary construction of Scandinavian national identities as modern, racially advanced and civilized, and knowledge on Sámi cultures, livelihoods and pastures was needed also for the purposes of governance of these vast lands (Mattson 2014; Bjørklund 2017). Even if the personal motivations of individual researchers might have varied, Lappology as a body of knowledge commissioned, funded and governed by Nordic states, is now seen as exemplary of a "nation-state science" whose ultimate function was to control populations and natural resources (Mattson 2014).

In contrast, "Sámi research" is generally associated with the rise of Sámi ethnopolitical movements and with demands for research managed and driven by the Sámi themselves. The roots of these demands are longer, reaching back to the first Sámi conference in Jokk- mokk in 1953, but in the 1970s Sámi calls for meaningful selfdetermination and decolo- nization of science became particularly intense and empowered by the broader rise of transnational anticolonial, anti-imperialist and minority discourses. Alf Isak Keskitalo's speech "Research as an inter-ethnic relation" at the 7th Nordic Ethnographic Conference in Tromsø in 1974 is generally considered to embody this paradigm change most clearly. In the speech, Keskitalo argued that until then, research relating to the Sámi had been shaped by a thoroughly static and asymmetric one-way relationship, in which Nordic ethnoscientists studied the Sámi people, and accumulated knowledge over them. However, this was bound to change, because the Sámi movement and emerging Sámi institutions were now capable of taking real measures to "convert the study relation completely", to dissolve earlier asymmetry, and to move the relationship to a new, "dynamic stage" (Keskitalo [1974] 1994, 14-15, 23).

Keskitalo also suggested several measures that would have to be taken. The first was to build research institutions that are based on Sámi values, needs, ideas and languages instead of those emanating from the dominant society. Second, such institutions would have to employ researchers who are Sámi themselves. Third, in addition to institution- building, the state would have to support and strengthen the development of research initiated by the Sámi through conscious funding decisions and strategies, because asymmetries in majorityminority relationships were reproduced also on the level of competition for funding and economic resources, where majority institutions still held the upper hand (ibid. 18-21).

Fourth, Keskitalo called for mechanisms and procedures to ensure and advance the practical application of Sámi expert knowledge and know-how, especially in matters with direct relevance to the Sámi themselves. He pointed out that the state needed new Sámi-led expert knowledge to administer the transition from a "static" to a "dynamic" stage in majority-minority relations (i.e. from an era in which the Sámi were only objects of Nordic governance to an era of Sámi self-determination and equality with the dominant society). Despite this, expert knowledge was executed according to majority rules, and possible minority representatives with "substantial and applied knowledge on the topic" were still ignored, or forced to transform their knowledge into forms that did them little justice (ibid. 15). Finally, and relating to the previous point, Keskitalo argued that also the epistemological and cognitive basis of what is considered as "proper" expert and scientific knowledge would need to be rethought, because as long as the Sámi would have to adapt knowledge of their own society and environment to the conventions of Western ethno-sciences, the majority would dominate (Keskitalo [1974] 1994, 10, 15).

\section{Sámi research as an ethico-political commitment and perspective}

The speech shows how academic knowledge was politicized as an aspect of the broader struggle for Sámi selfdetermination and nation-building in the social context of 1970s, which saw the expansion of political arguments to realms that were previously considered to lie outside of the political. In a single speech, Keskitalo also visited practically all the topics that have since then been central to debates regarding what "Sámi research" is and should be about. For instance, Keskitalo argued that although non-Sámi "Nordic ethno- scientists" could have a 
positive role in undoing asymmetries between the majority and minority, Sámification of research presupposed that the Sámi themselves would assume key roles within academia both as researchers and in institutional management. Especially in Norway, where the first Sámi research institutions were established around the time of Keskitalo's speech, intensive debates around the question of what such Sámification should mean in practice were central to the development of the research field during its first two or three decades.

Building on Thuen (1995), Stordahl (2008) argues that these debates have occupied "two different, yet related" discourses. On the one hand, they addressed the Sámi right to their own knowledge building, and questions of institutional access and control related to this right. Here, arguments have centred on the material aspects of research, and on the need to secure that Sámi themselves have the chance to determine the nature and purpose of research relating to them. Sámi access to the production of knowledge is necessary in order to undo existing asymmetries between the Sámi and the dominant society. Accordingly, the ethnic identity of the researcher matters, but mainly for ethnopolitical reasons.

On the other hand, Sámification has been understood as important not only in terms of control and access, but also for epistemological reasons. While Keskitalo did argue that "some of the phenomena in Sámi society could not be studied or described by groups other than the Sámi themselves" (Keskitalo [1974] 1994, 22-24), Stordahl points out that at times the argument has been interpreted not only as a call for a separate Sámi research paradigm built on Sámi theory of knowledge, but as an attempt to define Sámi research as a "culture-bound phenomenon", whereby researcher identity becomes equated with (Sámi) methodology and epistemology (Stordahl 2008, 257). On this interpretation, the ethnic identity of the researcher matters because the Sámi have a privileged access to insights and world-views required for Sámi research.

In practice, both interpretations have been extended to argue that only researchers who are Sámi can do Sámi research or contribute to its development, but such arguments have also been harshly criticized. For instance, it has been pointed out that cultural translation takes place every time a researcher tries to articulate a perspective on behalf of a given community, and also the "insider perspective" or world-view represented by ethnically Sámi scholars is always partial (Stordahl 1987, 2008; Thuen 1995, xii; Porsanger 2004, 109). It has also been argued that limiting the legitimate space of speech strictly to those who are ethnically Sámi does not strengthen the force of debates within Sámi research, because it risks excluding competent participants from discussion and "conveniently relieves insiders of finding answers to difficult counterarguments" (Otnes 2006, 140). Yet others recall how, following these debates, the atmosphere around Sámi research was at times highly uncomfortable, resulting in deep sense of de-legitimization of research by non-Sámi researchers, and in experiences of an academic dead-end (Larson 1988; Otnes 2006; Stordahl 2008, 250, 257). Accordingly, over the years the idea that only those researchers who are ethnically Sámi could contribute has been largely buried as untenable. Although "the antagonism between external and Sámi researchers becomes a subject of discussion from time to time", Lehtola writes, "the result has often been a statement that both are needed" (Lehtola 2017, 100; see also Hætta-Kalstad 2005, 39-40).

Eventually, then, the aspect of Keskitalo's argument that might remain least contested is the idea that Sámi research should benefit Sámi society and self-determination, rather than individual researcher careers or the governmental interests of the dominant society. For instance, Porsanger (2004), Kuokkanen (2008a, 2008b), Länsman (2008) and Mustonen (2012) emphasize the importance of ideas of accountability in Indigenous and Sámi research. All approve that also non-Sámi researchers can contribute to Sámi research, but they argue that before all else, such research has to be accountable to the Sámi community. In the present, these discussions seem to centre increasingly on ideas of community participation and research partnership, echoing similar developments in the broader field of Indigenous studies internationally. Instead of the ethnic identity of the researchers, academic interest is now directed to research methodologies that place the needs of Sámi communities at the centre of knowledge production, and to the devel- opment of ethical guidelines that would support such research (Kuokkanen 2008b; Drugge 2016; Juutilainen and Heikkilä 2016). This does not preclude questions of who can rep- resent the complexity of voices, interests and subject positions pertaining to Sámi commu- nities, or what kind of research is relevant from the perspective of Sámi societies and selfdetermination - discussing them within academia as well as on the community level is seen as central for the future development of Sámi research (Kuokkanen 2008b, 61; Länsman 2008, 91-93).

The roots of Sámi research are therefore deeply political, but as Lehtola $(2017,100)$ points out, many of the positions first held have "turned out more complex than what it was earlier believed". Nevertheless, one could argue that there is today a tentative con- sensus - at least on the level of definition - over what Sámi research is, 
or ought to be. For instance, Stordahl describes Sámi research as a "perspective that chooses to look at the relationship between the Sámi and Norwegian societies from the minority position" (Stordahl 2008, 262). Lehtola et al. define Sámi research as "research, which springs up from the needs of the Sámi society" (Lehtola, Piela and Snellmann 2012, 8; Lehtola 2012, 456-457) and Irja Seurujärvi-Kari describes it as "research, which takes the Sámi perspective into account" (Seurujärvi-Kari 2012, 60). What each share is an understanding of Sámi research as an ethico-political commitment related to Sámi societies: Sámi research is defined as research that proceeds from a Sámi perspective, or, at minimum, takes it into account.

Interestingly, then, although the idea that researchers doing Sámi research could only be Sámi themselves finds practically no support today, these definitions continue to anchor the field in an ethico-political commitment to "Sáminess of a perspective". This commitment constructs the definition and legitimacy of Sámi research both in terms of the politics of location and positioning (Sámi research proceeds from a Sámi perspective) and in terms of epistemology and research aims (Sámi research as a Sámi perspective). Accordingly, even though the question of individual researcher identity appears to have been resolved so that also non-Sámi researchers are welcome to contribute to Sámi research, and although it is also generally acknowledged that there is no one "authentic" Sámi perspective one could refer to, (Länsman 2008, 91-92), the ethico-political and epis- temological problematic associated with the question of "Sáminess" persists - it has just been moved to a different register, onto the level of "perspective". In the following, I will examine some challenges that this residual dependence on a priori ethnic definition is now introducing in Finland, where institutionalization of Sami research intersects with the multiplication of interests, hopes and desires that are articulated through research relating to the Sámi, and where questions over Sámi voice and identity have become a central aspect of struggles relating to Indigenous rights and self-determination vis-à-vis the Finnish state.

\section{Institutionalization in Finland}

The Sámi Instituhtta (SI) (the Nordic Sami Institute) was opened in Guovdageaidnu/ Kau- tokeino in Norway in 1973, with the official mandate "through research to strengthen and develop Sami language, culture and social life" from a Pan-Sámi perspective (Sámi Insti- tuhtta 2005). It was the world's first research institute which operated in the Sámi language and where the staff was predominantly Sámi (one of them being Keskitalo himself), and it has also been considered widely as an institution that responds primarily to Sámi societies' own needs (Juutilainen and Heikkilä 2016, 90-91; Keskitalo 2005, 24). At the beginning, Sámi Instituhtta was funded collectively by the Nordic states, but over time, Norway took primary responsibility. In 2005, the Sámi Instituhtta was moved under the umbrella of the Sámi University College, a national Sámi education institute in Norway, which is now aspiring to become a self-standing Sámi university (Juutilainen and Heikkilä 2016, 91-91). Other Norwegian universities, including Tromsø, Bergen and Oslo, are also active in Sámi research, and over the years, the Norwegian government has supported this field of research with considerable targeted funding (Magga 2009).

In Norway, institutionalization took place in a politicized social environment in which the nature of the relationships between the state and the Sámi, and the implications of colonialism for the politics of knowledge, were widely debated, culminating in the Alta dam controversy (Landsem 2017). In both Sweden and Finland, formal development of Sámi research as a self-consciously decolonizing field of inquiry has been weaker (Aikio and Aikio 2008; Juutilainen and Heikkilä 2016, 88-94; Drugge 2017, 9). In Finland, the first self-standing programme carrying the title "Sámi studies" was established at the University of Helsinki in 1993, but instead of reaching for a "paradigm change" grounded in the perspectives and needs of the Sámi themselves, its stated rationale was simply to bring together Sámi-themed research and expertise from different departments and disciplines within the university, such as linguistics, folklore and history. ${ }^{1}$

Giellagas Institute for Sámi Studies, which was established at the University of Oulu in 2001, presents a clearer break towards "new" Sámi research. Giellagas holds a nationwide responsibility for teaching and research in Sámi languages and cultures. Although its cur- riculum might lack an Indigenous studies framework (Kuokkanen 2008a), it is nevertheless profiled primarily as an institution seeking to work for, and benefit, Sámi society - this is articulated clearly, for instance, in Giellagas Professor Veli-Pekka Lehtola's inaugural speech (Lehtola 2005a). A significant part of the students and staff at Giellagas are Sámi by background, and it is currently the only academic institution in Finland where Sámi languages are used as the main working languages.

For the past decade, the University of Lapland has also engaged in intensive efforts to turn Sámi research into one of the university's main focus areas and "strategic spearheads" (Junka-Aikio 2011). Since its establishment in 
1979, research at the University of Lapland has been oriented towards Northern societies, including the Sámi, but under the first rector Esko Riepula (1979-2006) there was no consistent focus on developing Sámi research institutionally, or as a field of its own. Since 2010, however, the University of Lapland has sought for - and gained - nation-wide responsibility for research and teach- ing in Sámi Social Sciences and Sámi Legal Studies, established new study programmes in these fields, opened a number of new positions related to Arctic Indigenous and Sámi research, and established significant new collaboration agreements with other institutions relevant to the field, especially Giellagas (ibid). Today, the university's overall strategy and research profile presents Sámi research as central to teaching and research at the univer- sity across all the disciplines.

Moreover, Sámi research is taking a new, indigenous turn at the University of Helsinki, where it is currently developed not as a self-standing discipline (the old Sámi studies pro- gramme is facing closure), but as part of a brand-new Indigenous Studies programme established in 2016. The recently formed Helsinki Institute of Sustainability Science (HELSUS) is also developing expertise on Sámi issues as part of Arctic Indigenous sustainability research. In addition, there are plans to develop a new centre for Arctic Indigenous research and expertise, which aims to benefit from collaboration with Sámi researchers and institutions at universities in Finland and abroad, adjacent to the Sámi Education Insti- tute (Sogsakk) at Inari.

So, why has there been a "Sámi turn" in Finland's universities? And why right now, more than half a century after calls for a paradigm shift towards new Sámi research were first made? Next, I try to respond to these questions by discussing economic, social and political forces that are behind the current boom. The discussion focuses on three processes - Arctification, neoliberalization, and the rise of Indigenous Studies - and considers their potential impact on Sámi research as a critical field committed to Sámi self-determination.

\section{Arctification}

First, the current boom relates to the Arctification of Nordic political and economic inter- ests. As a result of climate change, the Arctic has become an object of increasing attention and interest. "Saving" the Arctic is said to be vital to prevent a massive sea level rise, and because the Arctic ecosystem holds a key role in preventing further warming. But the looming menace also casts the Arctic as a new "land of opportunity" abundant in exploi- table natural resources and new land and sea routes. Accordingly, in the past ten years, each state comprising the Sámi region - Finland, Sweden, Norway and Russia - has drafted its own national strategy for the Arctic.

Finland's Strategy for the Arctic Region was issued first in 2010, and updated in 2013 (Prime Minister's Office 2013). Although also environmental concerns and risks are discussed in the document, the overwhelming focus is on the development of resource extraction, logistics and infrastructure, and on general measures to strengthen Finland's position in the Arctic. Higher Education and research are a central means to pursue such aspirations: new expertise is needed, for instance, to invent technological solutions for industries which operate in the cold climate, to train a competent workforce, to increase Finland's scientific and political weight in the region, and to ensure that the pol- icies applied are environmentally and socially "sustainable". Thus, research is seen as a platform through which challenges and tensions relating to the changing Arctic can be resolved or reconciled, for instance through the development of green technologies and effective, sustainable governmental policies.

Accordingly, significant parts of Finland's Arctic Strategy focus on the importance of Arctic research and higher education, and on measures that are needed to consolidate Fin- land's positioning as a "leading world-class expert in the Arctic" (ibid. 23-26, 50-51). The promotion of "Sámi research" sits firmly within this category, and Sámi expertise at the University of Lapland, University of Oulu and The Sámi Education Institute (Sogsakk) are listed as examples of Finnish Arctic Research and Education (ibid. 25). From the perspective of Sámi research, this embrace is far from unproblematic, however. While the social sciences are valued due to their contributions for knowledge-based decision-making and social sustainability, research on the Sámi is needed because it facilitates the planning of socially sustainable policies amidst competing interests within the Sámi region. This understanding of science and society builds on a liberal perspective, which suggests that social and political conflicts result from lack of information and communication, rather than from irreconcilable difference, and that by "knowing" the society well enough, it is possible to accommodate different perspectives and interests.

And yet, the main objectives presented in Finland's Strategy for the Arctic Region 2013 appear fundamentally incompatible with Indigenous rights and Sámi interests. For instance, the document envisions a sharp increase in mining activities and large-scale improvement of extraction-oriented infrastructures in northern Finland. This 
runs counter to the fact that the Sámi Parliament in Finland has consistently opposed mining activities in the Sámi homeland area, due to its fatal effect on traditional Sámi live- lihoods, especially reindeer herding. Accordingly, if the ultimate aim of the Arctic Strategy is to ensure extraction of natural resources and to entrench Finland's presence in the Arctic region, then the framework of "sustainability" which grounds state support to Sámi research is a framework in which Sámi Indigenous rights are already, in principle, compromised.

\section{Neoliberalization}

Second, Arctification of governmental research policies intersects with the neoliberaliza- tion of the academy. Since the end of the 1980s, reforms designed to make universities "more responsive both to markets and to government priorities" (Shore and Wright 2017, 1) have thoroughly reshaped the conditions of academic knowledge-production. Especially in the English-speaking world, state funding has been largely withdrawn, causing tuition fees to sky-rocket, rendering academic careers increasingly precarious, and forcing universities to search for new income, for instance by partnering with private businesses and by attracting high-paying foreign students.

In Finland, university tuition remains cost-free and most of the funding still comes from the state, but neoliberal policies are transforming academic institutions also here. As an example, overall state support to universities has dropped, and now a staggering seventy-two percent of state funding allocated to universities is conditional and depen- dent on the university's ability to meet the criteria and targets set up by the government in one-to-one agreements. These agreements are negotiated every four years between the university and the Ministry of Education and Culture, and among other issues, they also cover the university's research profile and core areas of research (Ministry of Education and Culture (Finland) 2018). Importantly, universities in Finland are now required to refocus and redefine their research expertise and profile strategically, in order to grow their national and international relevance and competitiveness, and to differentiate them- selves from other universities in Finland and abroad. Additional (conditional) state-funds are allocated for each institution to implement such changes and there are plans to increase the percentage of such funds from twelve to fifteen.

It has been argued that neoliberal reorganization of the university is detrimental to democracy (Giroux 2002), to politically meaningful forms of diversity (Lehtonen 2009) and especially to the concerns of women and minorities (Blackmore 2017; Shore and Wright 2017, 4). Neoliberalism is also considered as a threat to those disciplines and research fields whose capacity to produce direct economic profit is less clear. What I suggest, however, is that in the particular context of Finland, emphasis on competitive- ness, and especially the demand that universities need to attend to their strategic research profiling, can also support certain marginalized disciplines and research areas, insofar as they fit in with the broader context in which various research policy calculations are made.

Although the general atmosphere in Finland is currently not particularly supportive of Indigenous rights for the Sámi, Sámi research does "fit in", at least formally. Finland's Arctic Strategy offers strong initiatives to develop expertise in Sámi research and to turn it into one of the institution's strategic assets. In northern Finland, this pairs well with another government expectation that universities should seek to grow their regional relevance, and to produce knowledge that is actually relevant to the society surrounding them. The Sámi are a local Indigenous community that is connected to the broader framework of the Arctic and Arctic Indigenous People. In the context of neoliberal funding policies, especially small universities in northern Finland may therefore find Sámi research highly pertinent for attempts to secure and increase their own relevance, particularly in the eyes of the Finnish government.

\section{Rise of Indigenous studies}

Thirdly, in addition to the needs of Arctic governance, Sámi research offers a promise of international scientific significance through its potential association with the much broader field of Indigenous studies, including Native, Aboriginal and First Nations studies. Indigenous studies as a discipline has grown steadily since the 1970s, but over the course of the 1990s and especially since the 2000s it has reached "critical mass", at least as far as the "concept of putting Indigenous studies scholars in dialogue globally and in a critical vein" is concerned (O'Brien and Warrior 2016, para 1). Several develop- ments have backed the process, including efficient organization and building of pro- fessional infrastructures (ibid.), the rise of Indigenous resistance movements such as the Zapatista movement (Laako 2008), and the international prominence of Indigenous rights discourses and construction of legal instruments which are compelling states to reconsider their relationship to Indigenous 
peoples. In addition, the broader popularity of critical, decolonial and deconstructive approaches within the humanities and the social sciences is generating growing interest in Indigenous studies.

In this context, Sámi societies and cultures may appear as a potentially trendy and dynamic area of study which connects well with academic discussions and developments elsewhere. This is not new as such: the rise of "Lappology" was also encouraged by Europe's appetite for exotic difference and also then academic engagement with the "Lapps" offered Scandinavian researchers and institutions a fast track to obtain international prestige and to secure access to the metropolitan centres of science (Lehtola 2005b; Mattson 2014).

To date, academic discourse has largely changed from "orientalist" to "Indigenous", but there are growing concerns that instead of supporting the disciplinary aims of Indigenous Studies, increasing interest and especially top-down institutionalization might actually weaken its connections and commitments to Indigenous communities, insofar as more and more scholars seek to refashion their work and expertise as "Indigenous" irrespective of their actual links to living Indigenous communities or disciplinary commitments (Cook- Lynn 1997; Grieves 2008; Andersen 2016). In North America, such concerns are coupled by enduring debates on "ethnic fraud", defined as "the deliberate falsification or changing of ethnic identities" in order to secure personal advantage in an institutional academic setting, for instance in the form of research funding, faculty positions, or admission to special programmes (Cook-Lynn 1993; Pewewardy 2004; Castagno and Lee 2007, 7; Pember 2010; Sturm 2010).

"Ethnic fraud" can be a real concern in a context in which "being indigenous" becomes institutionally valued, and when some positions are earmarked for representatives of Indi- genous communities. In practice, however, there are many tones of grey between outright fraudulence and genuine attempts to revive (long lost) indigenous identities. And yet, the impact of top-down institutionalization of Indigenous studies extends well beyond debates relating to researcher identity. One aspect worth addressing is: how does top-down support reshape the ecology of research interests around Indigenous research? Especially in the context of academic austerity and neoliberalism, researchers are increas- ingly compelled to fashion their work around funding incentives and opportunities. On the one hand, this means increasing governmental control over research questions, topics and approaches, which risk becoming "directed by think tanks, politicians and funding agencies rather than Native scholars or even Native populations" (Cook-Lynn 1997, 22). On the other hand, when discourses of Indigeneity and Indigenous participation become viewed as trendy buzzwords necessary to attract funding, more and more researchers are likely to fashion their research in these terms even when lacking the necessary training, background or cultural and community connection - or readiness to pursue them.

Whether (and how) such growing interest will strengthen Sámi research as a critical field of inquiry committed to Sámi self-determination, or merely result in academic "Sámi washing", 2 is a question which needs to be discussed properly. Current efforts to develop ethical guidelines for Sámi research present a welcome step towards this direc- tion (see Kuokkanen 2008b; Juutilainen and Heikkilä 2016).

\section{Rupture and continuity}

So far, I have argued that the on-going boom in Sámi research in Finland is supported by the Arctification of national interests, neoliberalization of the academy, and the international rise of Indigenous studies. Importantly, although institutional development of Sámi research is something that the Sámi themselves have long called for, the socio-pol- itical and economic context of this boom appears rather different from the context and conditions which framed the early institutionalization of "new" Sami research in Norway in the 1970s. At that time, institutionalization was backed by a growing Sámi movement and by a transnational surge of anticolonial and anti-imperialist struggles and discourses which generated strong support for Sámi selfdetermination, also among members of the Norwegian society at large (Otnes 2006; Landsem 2017). Although the early phase of institutionalization depended on state funding and top-down support, grass-roots pressure for building institutions that would genuinely support the paradigm change in the interests of the Sámi was rather strong.

Today, research relating to Sámi is again in increasing demand and efforts to institutionalize it have been stepped up, but this time largely to govern social and political changes associated with the Arctic resource rush and global warming, and in response to increasing pressures for academic specialization. Moreover, the present boom is taking place in a context in which Sámi political institutions appear increasingly weak and fragmented, and in which the development of Sámi self-determination and rights has been largely stalled, resulting in 
deteriorating relationships of trust between the state and the Sámi across the Nordic states (Lantto and Mörkenstam 2008; Bjørklund 2013; Guttorm 2018). From this perspective, the present conjuncture seems in many ways closer to the one that framed the relationships between the State and the Sámi in the "Lappologist" era, when research on the Sámi was needed to expand government control over the Sámi region and population, than to the "radical" 1970s when research was politicized openly, as an aspect of Indigenous self-determination.

Despite this, dominant narratives of contemporary Sámi research continue to define it in juxtaposition with Lappology. This juxtaposition is primarily qualitative (i.e. unlike Lap- pology, "Sámi research" proceeds from a Sámi perspective, or at least takes it into account), but it also has a temporal dimension. "New" Sámi research is presented readily as some- thing that comes after Lappology. In this manner, these narratives contribute to a depoliticized understanding of contemporary Sámi research: academic exploitation of the Sámi is narrated as something which belongs to the Nordic societies' colonial past, not the present, and definitely not to the field of "Sámi research" itself.

What the juxtaposition of "Lappology" and "Sámi research" fails to convey, is the fact that governments have never ceased interest in governing the Sámi, and academic decolonization is not an irreversible process that took place once and for all. The ways and dis- courses through which governmental interests and colonial asymmetries are articulated within research and the academia do change, however, and so should strategies of resistance and subversion. Perhaps, then, increasing government interest and support for research relating to Sámi should call for renewed efforts to rethink critically the politics of Sámi research, not only in terms of a rupture associated with the paradigm shift towards "new" Sámi research, but also in terms of continuity and repetition. How do colo- nial and asymmetric relations continue to be produced and reproduced in academic con- texts in the present, including in research that self-identifies as Sámi research, and what are their implications for critical thought and practice from the perspective of Sámi self- determination?

To be clear, I do not argue that institutionalization and top-down support are bad as such. On the contrary, it is hard to see how a field of study could be strengthened in their complete absence. What I do argue, however, is that the current increase in the volume of research seeking to associate itself with the Sami, and the fact that this field

ACTA BOREALIA 11

of research is receiving increasing support from the state, doesn't necessarily contribute to the original aims and agenda that Sámi research is identified with. At minimum, institutionalization needs to be accompanied by critical discussions over questions such as: what the purpose of Sámi research ought to be today, how legacies of colonialism are articulated in contemporary research environments, and what are the terms under which the discipline should be developed institutionally in the present. This would be particularly important in Finland, because unlike in Norway, such debates have barely been scratched here, and even Finnish colonization of Sami lands, let alone its implications for Sámi experi- ences in the present, are not really recognized by the public at large. Without critical engagement with these topics, efforts to institutionalize Sámi research are likely to reproduce existing "asymmetries" between the Sámi and the dominant society, rather than challenge them.

In the final part of the article, I elaborate on these thoughts by exploring briefly how the emergence of new struggles over Sámi voice and identity associated with the "non-status Sámi", "Forest Sámi” or "Forest Lapp" movements in Finland is challenging and reshaping the political terrain of Sámi research.

\section{New struggles over Sámi voice and identity}

Sámi cultural autonomy was institutionalized in Finland in 1995 with the establishment of the Sámi Parliament. At first, political institutionalization seemed to encourage dissociation between Sámi research and Sámi ethnopolitics. Lehtola and Länsman $(2012,15-20)$ write that in the 1970s and 1980s, when the Sámi ethnopolitical movement was still young, different "fields" within Sámi society, such as politics, the arts, media and research, were intensively entangled through their shared commitment to Sámi nation-building. Everything from poetry to journalism and academic research was linked to efforts to construct a new, shared Sámi vision.

This changed in the 1990s alongside the establishment of the Sámi Parliament. Former antagonism between the Sámi and the state gave way to negotiations and dialogue, and politics became more professionalized, but centralization of political leverage gave rise also to new frictions and struggles within Sami society. In this new 
context, Lehtola and Länsman argue, politics began to separate from the other fields. Arts and sciences were "freed" from the grip of Sámi ethnopolitics, and began to look for new references and connections, no longer motivated to contribute to just one vision of Sámi society and culture. Accordingly, Lehtola and Länsman (2012, 21-26, 32) write that in the post-institutionalization phase, each field has developed in diverse directions and in its own, idiosyncratic ways. In the context of Sámi literature, Lehtola has described this period in terms of individualization and serenity (ibid. 15 and Lehtola 1995), and in the context of Sámi research, as a period of depoliticization and methodological and thematic diversification (Lehtola 2011).

However, in addition to diversifying Sámi social and cultural life, institutionalization of Sámi politics and rights provoked entirely new identity projects and struggles, which are described in detail in Lehtola's later book, Saamelaiskiista (Lehtola 2015). The book explains how, in the 1990s, the establishment of the Sámi Parliament and especially the prospect that the state would ratify the ILO 169 agreement concerning Indigenous peoples, which also covers Indigenous Land Rights, spawned new anxieties within local Finnish communities, which feared that their own rights to the area would be endangered. Consequently, these communities mobilized to strongly oppose Sámi rights, while also trying to gain access to the Sámi Parliament's electoral roll, which began to be seen as a ticket to possible benefits allocated to the Sámi. In this context, many started to examine their ancient family histories in the hope of finding at least one Sámi ancestor. But, as Lehtola points out, often the same individuals were actively opposed to Sámi Indi- genous rights and especially the ratification of the ILO 169 (Lehtola 2015, 12-14).

Over time, the rhetoric of this "locally based counter-movement against Sámi ethnopolitical mobilisation" (Pääkkönen 2008) has varied. Its proponents have argued, for instance, that the Sámi do not exist at all, because "we are all the same", and the Sámi were actually invented for political purposes and gains. On other occasions, it has been argued that those who call themselves Sámi are immigrants who came from Norway, displacing "Lapps", the "true Indigenous people in Finland" whose descendants, and not the Sámi, should be the actual beneficiaries of the ILO 169 (Pääkkönen 2009, 87-100). More recently, the argument has shifted largely to a claim that there exist groups of Sámi who have been unduly left out of the Sámi Parliament's electoral roll because the Sámi Parliament's understanding of Sáminess is too narrow and exclusivist (see Aikio and Åhren 2014; Junka-Aikio 2016, 2018).

These changes in the movement's rhetoric are paralleled by a shift in the mode and platform of argumentation, which has become increasingly professional and academic, and focused on the production and dissemination of research and expert knowledge. The "academic turn" might have begun a decade earlier (Pääkkönen 2008, 100111, 253-261), but it has intensified sharply during the past ten years, especially since the pub- lication of Erika Sarivaara's PhD thesis Statuksettomat saamelaiset: paikantumisia saamelaisuuden rajoilla (Sámi without Status: On the Edge of Sámi Culture), which was defended at the University of Lapland in June 2012. The thesis launched a new notion of "non-status Sámi" to describe and articulate a group of people who have Sámi ancestry (no matter how distant), but are currently not included in the Sámi Parliament's electoral roll. Subsequently, the thesis argued that the legal definition of the Sámi should be made more inclusive in Finland, so that such people could join the electoral roll and have their identity formally acknowledged. In the following month, the author also established a new organization to represent the "non-status Sámi" and advance their rights. Since then, the organization, which was first named MGDS and then VGDS, ${ }^{3}$ has been highly active at mobilizing support on local and national level, and it has also forged extensive political networks, especially in the Central Party, which is the third largest party in Finland and particularly strong in Lapland, where it holds a majority of the seats.

Importantly, Sarivaara's thesis has been followed by a profusion of other related litera- tures. These literatures range from texts written by amateurs such as the book Kemin-Lappi elää! Alkuperäiskansa keminlappalaiset: Yksi Suomen neljästä saamelaisryhmästä (Kemi- Lapland Lives! The Indigenous People Kemi-Lapps: One of the Four Sámi Groups in Finland) (2016) ${ }^{4}$ edited by Eeva-Liisa Maijala, who is a Lappish MP for the Central Party, to academic theses, articles and compiled volumes. There is no space to list all of them here, but central pieces include, for example, Tanja Joona's PhD thesis (2013) and several articles which link the question of legal Sámi definition with questions relating to the possible ratification of the ILO Convention n. 169. In addition, we find Juha Joona's articles and a recent PhD thesis (2019), an edited volume titled Kuka on saamelainen ja mitä on saamelaisuus? Saamelaisuuden juurilla (Who is Sámi and What is Sáminess: at the Roots of Sáminess) (Sarivaara, Määttä, and Uusiautti 2013), ${ }^{5}$ which builds on papers presented at a seminar orga- nized by the VGDS, and another one titled Lapin taivaan alla (Under Lapland's Sky) (Kaisanlahti 2018), ${ }^{6}$ which is based on presentations held at the first "Forest Lapp Days", convened by a new organization also headed by the Central Party MP Maijala. ${ }^{7}$ At the same time, the notion of "non-status Sámi" has given way to other appropriated group 
names that have more positive substance and historical grounding, such as "Forest Sámi" or "Forest Lapps". Alternatively, many people identifying with the political agenda of the VGDS now claim to be part of Inari Sámi, which is one of the three Sámi groups (others being North Sámi and Skolt Sámi) represented by the Sámi Parliament in Finland.

\section{Neo-politicization of Sámi research}

These kinds of identity projects are not unique to Finland. Similar developments are taking place in many parts of the world where the resurgence of Indigenous identities and societies has been coupled with concrete advances on the level of Indigenous rights and autonomy. This is the case especially in Canada and the United States, where Indigenous communities are increasingly challenged by new groups and individuals who are also claiming Indigenous identities and tribal membership, mainly on the basis of distant ancestry (see Andersen 2008, 2014; Sturm 2010; Tuck and Yang 2012; Gaudry and Leroux 2017; Gaudry 2018; Reflections on the Daniels Decision 2018; Valkonen, Kotiranta, and Tervaniemi 2018; Leroux 2019). This new rush to Indigeneity might be grounded, in part, in the success of Indigenous revival and in the fact that within postmodern fragmented societies, ethnic and Indigenous identities might appear increasingly attractive. However, recent scholarship is placing the phenomenon increasingly in line with settler colonial revisionism, arguing that analyses of these identity projects might eventually tell us more about "the shifting politics of whiteness" in settler colonial societies, than about Indigeneity as such (Leroux 2019, 4).

Accordingly, there are growing concerns within Indigenous Studies with the challenge that these movements present in relation to Indigenous self-determination and decolonization (Andersen 2008, 2014; Sturm 2010; Tuck and Yang 2012; Gaudry and Leroux 2017; Gaudry 2018; Gaudry and Andersen 2018; Reflections on the Daniels Decision 2018; Leroux 2019). The issue these scholars tackle is not bloodlines or notions of authenticity and "racial purity"; on the contrary, it is asserted that Indigenous Peoples do not tend to view identity and community membership in racial terms and that racialization of indigenous peoplehood is precisely part of the problem. Rather, concerns abound around the fact that instead of grounding identity claims in companionship with living indigenous communities, these movements focus on the past and on long lost ancestry, use discourses of individual self-identification to override the Indigenous right to collectively determine membership in the group, and typically position themselves in direct antagonism with formally recognized Indigenous communities and their political and community representation through discourses of victimization, resentment and superiority (ibid.). Accordingly, the genealogy of the "race shifting" phenomenon (Sturm 2010) has been traced largely to the history of the settler colonial need to either oppose or appropriate Indigenous identities and culture.

Reading these literatures, it is striking how many parallels there are between "new Indian" and "new Métis" movements and the "non-status Sámi" or "Forest Lapp" movements in Finland. However, what might differ is the extent of political leverage that the movement has been able to gain in Finland, compared to that in Canada and the US. For instance, Lehtola $(2015,15)$ writes that for a long time the thoughts and myths disseminated by the early "Lapp" movement, which began in the mid-1990s, seemed to him too comical to be considered or engaged seriously. By 2015, however, such arguments (now laced with references to research knowledge and concepts taken from academic theses) were circulated densely within the Finnish Parliament, to back the decision to put down two legal propositions with high importance for the Sámi - the one concerning the ratification of the ILO 169 , and the other concerning the reform of the Sámi Parliament Act.

Later in the same year, the Finnish Supreme Administrative Court decided to forcefully include 93 new persons in the Sámi Parliament's electoral roll, against the earlier judgement and decision by the Sámi Parliament and its Electoral Committee. Labba (2018) argues that this was in actual breach of the Sámi Parliament Act itself, and in February 2019, the United Nations' Committee for Human Rights stated that in so doing, the Supreme Administrative Court actually "infringed on the capacity of the Sámi people, through its Parliament, to exercise a key dimension of Sámi self-determination in determining who is a Sámi". The Committee also demanded that the state of Finland take immediate action to remedy the violation of Sámi rights in this case. ${ }^{8}$

Yet, in a national Finnish context, new claims to Sámi identity have found a highly receptive ground, and in an astoundingly short time have become a rather naturalized part of academic and political discourses pertaining to the Sámi. In just three years, the notion of "non-status Sámi" travelled from Sarivaara's PhD thesis, where it was first mentioned, to government policy debates and documents and actual decision-making (Länsman and Kortelainen 2017). Furthermore, the idea of "Forest Lapps" is now used increasingly as an unproblematic 
category of analysis in both commissioned government reports (Prime Minister's Office 2018-2019) and publicly funded research (Toivanen 2016). Why this might be the case is a topic I have already explored in detail elsewhere (Junka- Aikio 2016). In practice, however, the development of Sámi rights in Finland is currently almost at a halt, in large part because the state now considers the question of who is a Sámi, and thus subject of such rights, too unclear.

The impact of these campaigns on state policy and Sámi self-determination is beginning to attract researchers' attention (Aikio and Åhren 2014; Lehtola 2015; Junka-Aikio 2016, 2018; Länsman and Kortelainen 2017). But what has not been considered properly so far is the question of how the construction of new claims over Sámi identity, and especially their insertion into the academic field, is reshaping the political terrain of Sámi research itself. Importantly, the texts and literatures associated with the movement do not only examine Sámi identity and politics: they make a claim to represent a Sámi voice and perspective, and hence position themselves in direct line with "new" decolonial Sámi research. As an example, Maijala's semi-academic book claims to bring out voices from within a "forgotten" Sámi community, and the book Who is Sámi and What is Sáminess is promoted openly as "representative of Sámi research at the University of Lapland". 9

Sarivaara's own thesis is fluent in concepts and approaches relevant for Indigenous and postcolonial studies, and it was published as part of the Dieđut book series at the Sámi University College in Guovdageaidnu/Kautokeino, Norway. Later in the same year, the board of the Israel Ruong Foundation at the Sámi University College decided to nominate Sarivaara for the biennial Israel Ruong prize, which is destined for promising researchers who are ethnically Sámi. In the Finnish side of the Sámi region, where the broader political context of the author's arguments was better known, the nomination raised protests. Five major Sámi organizations in Finland issued a collective statement against the nomination, arguing that Sarivaara was not Sámi, and therefore could not be nominated for a prize reserved for a Sámi person. Soon, the Sámi Council, the president of the Sámi Parliament in Finland, and a number of key researchers at the Sámi University College itself issued similar statements. ${ }^{10}$ In addition, the formal procedure leading to the nomination came under scrutiny when it was revealed that instead of the required three members of Sámi University College's leadership, only two were involved in the nomination. ${ }^{11}$ As a result, the prize was handed over to Sarivaara, but with a significant delay and amidst massive controversy, which saw much of the faculty at the Sámi University College boycott the actual award festivities. $^{12}$

\section{From the politics of definition to politics of Sámi research}

The case of the "non-status Sámi" demonstrates how, in the past years, Sámi research has again become a central arena of ethnopolitical production. This time, however, politicization of research has been driven largely by actors and groups whose policy goals and collective genealogies side with a broader movement that has developed to challenge and oppose the development of Sámi Indigenous Rights in northern Finland, especially in the context of the ILO 169. This trend towards neo-politicization of Sámi research is presenting new and rather difficult questions to the academic community. If "Sámi research" is defined as research that "proceeds from a Sámi perspective", should all research which identifies itself as such be considered as "Sámi research"? If not, then how is one to engage with the politics of such framing? Who can say which research "proceeds from a Sámi perspective" and which does not?

Such questions are not only uncomfortable, but also highly problematic, insofar as they point towards a need for academic gate-keeping around the "Sáminess of perspective". In addition to being ethically suspect, such gatekeeping would be intellectually atrophic. This is precisely the reason why the idea that only researchers who are Sámi could contribute to Sámi research has also by now been largely abandoned. The real question, then, is not about how to define and enforce the boundaries of "Sámi research". Rather, the question is, what forms of criticism, other than "gate-keeping", are available for critical engagement with research texts which claim to represent Sámi voice and perspective, especially when the act of claiming that perspective and position constitutes a central aspect of their political objectives and strategy? How to draw attention to such politics and such underlying agendas, when these texts' self-identification as "Sámi research" suggests that they simply articulate one of many "equally Sámi" voices and perspectives in the context of a multicultural society and an increasingly diverse research field?

In response to research and arguments advanced by proponents of the "non-status Sámi" movement, one strategy that has been tried is disengagement. At first, many scholars felt that by engaging these new texts one would just contribute to their academic credentials and heightened visibility, and therefore these arguments and 
texts would be best left alone, in silence. ${ }^{13}$ But this strategy clearly hasn't worked. Critical research, which engages the range of tensions, interests and desires which are articulated in the name of contemporary Sámi research, and which makes them visible, presents another possible strategy. That it is the mode of criticism that I have tried here.

\section{Conclusions}

This article has argued that instead of reflecting the empowerment of Sámi society, on- going institutionalization processes in Finland are framed by the government's quest for Arctic relevance and by a rising need to navigate the tensions and contradictions between environmental and social sustainability and extractive policies in the context of the warming Arctic. Moreover, current institutionalization is backed by the neoliberalization of academia, as a result of which universities are increasingly forced to compete for funding and to increase their relevance to the state through strategic profiling, and by the rise of Indigenous studies which is contributing to Sámi research an air of growing inter- national relevance. Together, these processes are compelling institutions and individual researchers alike to turn increasingly towards issues relating to the Sámi.

Next, I argued that formal institutionalization and the parallel increase in the volume of research relating to the Sámi does not, in itself, guarantee that the original purposes of the academic endeavour - its commitment to decolonization and Sámi self-determination - are being advanced. At minimum, institutionalization needs to be accompanied by real debate over the legacy of Nordic colonialism and its articulation in the present. Such debate will find support in on-going efforts to create ethical guidelines for research relating to the Sámi.

Finally, I argued that in Finland, Sámi research has become one of the key sites where new claims over Sámi identity and Sáminess are made and consolidated. So far, the primary addressee of these identity claims has been the Finnish state, and in practice the focus has been on efforts to hold back the development of Sámi Indigenous rights and self-determination, unless access to those rights and political institutions is radically expanded. This process of neo-politicization presents entirely new challenges: how to respond to new political and identity struggles that are articulated in the name of Sámi research, but linked to a movement whose policy goal is to challenge and ultimately undermine collective Sámi self-determination?

Eventually, both processes - top-down institutionalization and neo-politicization - problematize the continued viability of defining Sámi research as "research, which proceeds from a Sámi perspective, or at least takes it into account". Although the ethico-political definition has never been unproblematic, it might have performed reasonably well in the social and political context of the 1970s and 1980s, which presented strong Sámi movements and reliable general support for Sámi self-determination, and even up until the formalization of Sámi autonomy through the Sámi Parliaments in the 1990s. However, in the conjuncture of institutionalization and neo-politicization that I have analyzed here, definitions of Sámi research which focus on its political and ethical qualities ("Sámi research" as research done from the "Sámi perspective" or which "takes the needs of the Sámi into account") appear increasingly inoperative, and might actually end up doing the opposite of what was originally intended. Instead of bringing questions regarding the politics of per- spective, location, representation and power/knowledge to the fore, such definitions actually turn attention away from the very broad variety of interests, desires and subject positions that currently are projected onto Sámi research. If Sámi research is defined a priori as "research which proceeds from a Sámi perspective", then everyone who presents his/her research as "Sámi research" is already making a statement in regard to his/her positioning, foreclosing attention from the complex (political) context of forces, interests and conditions of possibility which in the first place constitute its rationale.

To conclude, institutionalization and top-down support are necessary to strengthen Sámi research as a critical research field committed to Sámi self-determination, but there are no guarantees they will end up doing so. As Cook-Lynn argues, "Indigenous studies was not created to ensure the reproduction of universities and legitimacy, if it means that Indigenous peoples do not also benefit" (cited in Andersen 2016, Section 3/ Part 2, para. 2). With this article, I hope to open up discussion and debate, among both individual researchers and academic institutions, over what this might mean in the Sámi context today.

\section{Notes}

1. According to the founders of the programme, the aim was to "prepare students for workpositions which relate to Lapland and the Calotte areas, to Sami issues, to Indigenous people, and to Nordic and broader international 
cooperation", and secondly, to "satisfy the general, in part scientific, interest that is felt towards the Sami also abroad" (Kulonen, Pentikäinen, and Seur- ujärvi-Kari 1994, 10-11).

2. The notion of "Sámiwashing" was first coined by Dr.Tiina Seppälä in the context of an informal conversation in Spring 2011.

3. MGDS stood for "Meahcce-, guolásteaddji- ja duottar sámit" in Northern Sámi, meaning "Forest, Fishing and Mountain Sami." When it was discovered that the word "meahcce" was semantically incorrect in this context, the word was replaced by "vuovde" and the acronym changed to VGDS.

4. Title translated from the Finnish original by the author.

5. Title translated from the Finnish original by the author.

6. Title translated from the Finnish original by the author.

7. https://www.metsalappalaiset.net.

8. Views adopted by the Committee under article 5(4) of the Optional Protocol, concerning communication No. 2668/2015, available online at https://www.samediggi.fi/2019/02/01/un- human-rights-committee-thedecisions-of-the-supreme-administrative-court-of-finland-on- the-electoral-roll-of-the-sami-parliaments-electionin-2015-were-a-violation-of-human- rights/?lang=en [accessed 22 March 2019].

9. https://www.ulapland.fi/news/Kuka-on-saamelainen-ja-mita-on-saamelaisuus-Identiteetinjuurilla/njqhyjsl/d9127888-9ae8-44e6-ad0c-d8ce6f20c025. Retrieved 7 January 2019.

10. Yle Sápmi (online) 13 May 2013, "Suoma Sámesearvvit vuostalastet Ruong-balkkasupmi geigema Sarivaarai" https://yle.fi/uutiset/osasto/sapmi/suoma_samesearvvit_vuostalastet_ruongbalkkasumi_geigema_sarivaarai/6638150 (in Northern Sami); https://yle.fi/uutiset/ osasto/sapmi/saamelaisjarjestot_vastustavat_sarivaaran_palkitsemista/6638420 (in Finnish) Retrieved 4 October 2018.

11. Yle Sápmi (online) 4 June 2013. "Säätiöhallitus ei ollut täydellinen Israel Ruong - stipendistä määrätessään" https://yle.fi/uutiset/osasto/sapmi/nrk_saatiohallitus_ei_ollut_taydellinen_israel_ruong_stipendista_maaratessaan/6672818. Retrieved 7 January 2019.

12. Yle Sápmi (online) 6 November 2013. “Saamelaisen korkeakoulun kärkitutkijat eivät hyväksy Israel Ruong menettelyä." https://yle.fi/uutiset/osasto/sapmi/saamelaisen_korkeakoulun_ karkitutkijat_eivat_hyvaksy_israel_ruong_-menettelya/6919256. Retrieved 7 January 2019.

13. This view came across quite frequently in the context of private discussionsI have had with other scholars associated with the Sámi research community in Finland, especially during the period between the years 2012 and 2015.

\section{Acknowledgements}

I thank warmly all those who have helped me think through the topics covered in this article, however I alone carry responsibility over the final text. Particular thanks go to Antti Aikio, Marjut Aikio, Pekka Aikio, Ivar Bjørklund, Lydia Heikkilä, Outi Korpilähde, Hanna Laako, Veli-Pekka Lehtola, Mikko Lehtonen, Darryl Leroux, Anni-Siiri Länsman, Tiina Seppälä, Tomi Tuominen, the anonymous reviewers of Acta Borealia and all researchers in the Sodi-Sámi research project which is based at the Tromsø University Museum, UiT Arctic University of Norway.

\section{Disclosure statement}

No potential conflict of interest was reported by the author.

\section{Funding}

This work was supported by Norwegian Research Council [grant number 270629].

\section{References}

Aikio, Antti, and Matias Åhren. 2014. "A Reply to Calls for an Extension of the Definition of Sámi in Finland.” Arctic Review on Law and Politics 1: 123-143.

Aikio, Marjut, and Antti Aikio. 2008. Saamelaiset - rajoin rikottu kansa. Internal memorandum for the University of Lapland, January 15.

Andersen, Chris. 2008. "From Nation to Population: The Racialisation of "Métis" in Canadian Census." Nations and Nationalism 14 (2): 347-368.

Andersen, Chris. 2014. Métis: Race, Recognitions and Struggle for Indigenous Peoplehood. Vancouver: UBC Press. 
Andersen, Chris. 2016. “Critical Indigenous Studies: Intellectual Predilections and Institutional Realities.” In Critical Indigenous Studies: Engagements in First World Locations, edited by Aileen Moreton-Robinson. A Kindle eBook. Tucson: University of Arizona Press.

Bjørklund, Ivar. 2013. "Industrial Impacts and Indigenous Representations: Some Fallacies in the Sámi Quest for Autonomy.” Études/Inuit/Studies 37 (2): 145-160.

Bjørklund, Ivar. 2017. “On the Relations Between Society and Knowledge Production.” A paper pre- sented at Sodi-Sámi workshop, Tromsø University Museum, May 18.

Blackmore, Jill. 2017. “Leadership in Higher Education: A Critical Feminist Perspective on Global Restructuring.” In Death of the Public University? Uncertain Futures for Higher Education in the Knowledge Economy, edited by Cris Shore and Susan Wright, 90-116. New York: Berghahn Books.

Castagno, Angelina, and Stacey Lee. 2007. "Native Mascots and Ethnic Fraud in Higher Education: Using Tribal Critical Race Theory and the Interest Convergence Principle as an Analytical Tool." Equity and Excellence in Education 40 (1): 3-13.

Cook-Lynn, Elizabeth. 1993. 'Meeting of Indian Professors Takes up Issues of 'Ethnic Fraud,' Sovereignty, and Research Needs.” Wicazo Sa Review 9 (1): 57-59.

Cook-Lynn, Elizabeth. 1997. “Who Stole Native American Studies?” Wicazo Sa Review 12 (1): 9-28.

Drugge, Anna-Lill, ed. 2016. Ethics in Indigenous Research: Past Experiences - Future Challenges. Umeå: Vaartoe Centre for Sami Resarch.

Drugge, Anna-Lill. 2017. “How Can We Do it Right? Ethical Uncertainty in Swedish Sami Research.”

Journal of Academic Ethics 14: 263-279.

Gaudry, Adam. 2018. “Communing with the Dead: The 'New Métis', Métis Identity Appropriation and

the Displacement of Living Métis Culture.” American Indian Quarterly 42 (2): 162-190.

Gaudry, Adam, and Chris Andersen. 2018. "Daniels v. Canada: Racialized Legacies, Settler Self- Indigenization and the Denial of Indigenous Peoplehood.” TOPIA: Canadian Journal of Cultural Studies 36: 19-30.

Gaudry, Adam, and Darryl Leroux. 2017. "White Settler Revisionism and Making Métis Everywhere: The Evocation of Métissage in Quebec and Nova Scotia." Critical Ethnic Studies 3 (1): 116-142.

Giroux, Henry. 2002. "Neoliberalism, Corporate Culture, and the Promise of Higher Education: The University as a Democratic Public Sphere." Harvard Educational Review 72 (4): 425-464.

Grieves, Vicky. 2008. “The 'Battlefields': Identity, Authenticity and Aboriginal Knowledges in Australia.” In Indigenous Peoples: Self-Determination, Knowledge and Indigeneity, edited by Henry Minde, 287-311. Delft: Eburon.

Guttorm, Juha. 2018. Saamelaisten itsehallinto Suomessa - dynaaminen vai staattinen? Acta Universitatis Lapponiensis 375. Rovaniemi: University of Lapland.

Hall, Stuart. 1992. “Cultural Studies and its Theoretical Legacies.” In Cultural Studies, edited by

Lawrence Grossberg, Cary Nelson, and Paula Treichler, 277-229. New York and London: Routledge.

Hætta-Kalstad, Johan Klemet. 2005. “Sámi Instituhta vuosttaš 30 jagi: politihkalaš vákšun ja sami dutkán.” In Sami Instituhtta - 30 jagi. Raporta Sámi Institutta 30-jagi ávvudeamis 28.10.2004, 24-29. Kautokeino: Sámi Instituhtta.

Hirvonen, Vuokko. 1999. Saamenmaan ääniä. Helsinki: SKS.

Joona, Tanja. 2013. The ILO Convention No. 169 in a Nordic Context with Comparative Analtsis: An Interdisciplinary Approach. Rovaniemi: University of Lapland Press.

Joona, Juha. 2019. Immemorial Right - Research on Lapland's Land and Water Rights. Juridica Lapponica 46. Rovaniemi: Arctic Centre and University of Lapland.

Junka-Aikio, Laura. 2011. “Saamentutkimus saapui Lappiin.” Kide 2: 8-12. 
Junka-Aikio, Laura. 2016. "Can the Sami Speak Now? Deconstructive Research Ethos and the Debate on Who is a Sámi in Finland.” Cultural Studies 30 (2): 205-233.

Junka-Aikio, Laura. 2018. "Indigenous Culture Jamming: Suohpanterror and the Articulation of Sami Political Community." Journal of Aesthetics and Culture 10 (4). doi:10.1080/20004214.2017. 1379849.

Juutilainen, Sandra, and Lydia Heikkilä. 2016. "Moving Forward with Sámi Research Ethics: How the Dialogical Process to Policy Development in Canada Supports the Course of Action for the Nordic Countries." In Ethics in Indigenous Research: Past Experiences - Future Challenges, edited by Anna- Lill Drugge, 81-116. Umeå: Vaartoe Centre for Sami Research.

Kaisanlahti, Janne, ed. 2018. Lapin taivaan alla 1: Metsälappalaispäivien vuosikirja. Rovaniemi: Metsälappalaispäivät ry.

Keskitalo, Alf Isak. [1974] 1994. Research as an Inter-Ethnic Relation. Arctic Centre Reports, 11. Rovaniemi: Arctic Centre and the Sami Instituhtta.

Keskitalo, Alf Isak. 2005. “Sámi Instituhtta - Muittašeapmi.” In Sami Instituhtta - 30 jagi. Raporta Sámi Institutta 30-jagi ávvudeamis 28.10.2004, 24-29. Kautokeino: Sámi Instituhtta.

Kulonen, Ulla-Maija, Juha Pentikäinen, and Irja Seurujärvi-Kari. 1994. “Alkusanat.” In Johdatus saamen- tutkimukseen, edited by Ulla-Maija Kulonen, Juha Pentikäinen, and Irja Seurujärvi-Kari, 7-12. Helsinki: SKS.

Kuokkanen, Rauna. 2008a. "Sami Higher Education and Research: Towards Building a Vision for Future." In Indigenous Peoples: Self-Determination, Knowledge, Identity, edited by Henry Minde, 267-289. Delft: Eburon.

Kuokkanen, Rauna. 2008b. "From Research as Colonialism to Reclaiming Autonomy: Toward a Research Ethics Framework in Sápmi.” In Ethics in Sámi and Indigenous Research: Report from a Seminar in Kárášjohka, Norway 23-24.11.2016, Sámi Instituhtta Raporta 1, 48-63. Alta: Fagtrygge Idé.

Laako, Hanna. 2008. "Latin American Critical Inquiry and the Nature of the Political in the Era of Globalization." Latin American Perspectives 35 (6): 93-105.

Labba, Oula-Antti. 2018. “Kokonaisharkinta korkeimman hallinto-oikeuden vuosikirjapäätöksissä koskien saamelaismääritelmän tulkintaa." Pro-gradu thesis, Faculty of Law, University of Lapland. Landsem, Lena. 2017. "Research Into Minorities: Between Science and Politics." Arctic and North 27: 147-169.

Länsman, Anni-Siiri. 2008. “Kenelle saamentutkija tutkii?” In Tutkijan Kirja, edited by Kirsti Lempiäinen, Olli Löytty, and Merja Kinnunen, 87-89. Tampere: Vastapaino.

Länsman, Anni-Siiri, and Terttu Kortelainen. 2017. "Issue Publics and the Concept of Non-status Saami: A Study of Diffusion, Reframing and Implementation.” Paper presented at the Sodi-Sámi Reading Seminar, Tromsø University Museum, January 22, 2018.

Lantto, Patrik, and Ulf Mörkenstam. 2008. “Sami Rights and Sami Challenges.” Scandinavian Journal of History 33 (1): $26-51$.

Larson, Karen. 1988. “Ethnopolitics and Research Ethics for the Non-Native Researcher.” Acta Borealia 5 (1-2): 5-21.

Lehtola, Veli-Pekka. 1995. Saamelaiset: Historia, Yhteiskunta, Taide. Jyväskylä: Kustannus-Puntsi. Lehtola, Veli-Pekka. 2005a. "Saamelaiset itse tutkimuksen tekijöiksi." Virkaanastujaispuhe. Kaltio 61 (5): 254-257.

Lehtola, Veli-Pekka. 2005b. “'The Right to One’s Own Past'. Sámi Cultural Heritage and Historical Awareness.” In The North Calotte: Perspectives on the Histories and Cultures of Northernmost Europe, edited by Maria Lähteenmäki and Päivi Maria Pihlaja, 83-89. Inari: Kustannus-Puntsi.

Lehtola, Veli-Pekka. 2011. “Tiedettä tieteen ehdoilla.” (Interview by Laura Junka-Aikio). Kide 2 (11).

Lehtola, Veli-Pekka. 2012. Saamelaiset suomalaiset: Kohtaamisia 1896-1953. Helsinki: SKS.

Lehtola, Veli-Pekka. 2015. Saamelaiskiista. Helsinki: Into.

Lehtola, Veli-Pekka. 2017. "Vanishing Lapps, Progress in Action. Finnish Lappology and Representations of Sámi in Publicity in the Early 20th Century." Arctic and North 27: 83-102. 
Lehtola, Veli-Pekka, and Anni-Siiri Länsman. 2012. “Saamelaislikkeen perintö ja institutionalisoitunut saamelaisuus.” In Saamenmaa: Kulttuuritieteellisiä näkökulmia, edited by Veli-Pekka Lehtola, Ulla Piela, and Hanna Snellman, 13-35. Helsinki: SKS.

Lehtola, Veli-Pekka, Ulla Piela, and Hanna Snellman. 2012. "Haastava Saamenmaa." In Saamenmaa: kulttuuritieteellisiä näkökulmia, edited by Veli-Pekka Lehtola, Ulla Piela and Hanna Snellman, 7- 10. Helsinki: SKS.

Lehtonen, Mikko. 2009. "Spaces and Places of Cultural Studies." Culture Unbound: Journal of Current Cultural Research 1: 6781.

Leroux, Darryl. 2019. Distorted Descent: White Claims to Indigenous Identity. Winnipeg: University of Manitoba Press.

Magga, Ole Henrik. 2009. “Sámi dutkama ruhtadeapmi ja organiseren - Norggas ja olles Sámis.” In Sámi Oahpahus, Sámi dutkan, Sámi ásahus: Sámi allaskuvla 20 jagi, edited by Jan Henry

Keskitalo, Kristine Nystad, and Torunn Pettersen, 79-86. Kautokeino: Sámi University College. Maijala, Eeva-Liisa, ed. 2016. Kemin-Lappi elää! Alkuperäiskansa keminappalaiset: Yksi Suomen neljästä saamenryhmästä. Kemijärvi: Pihkassa Lapin luontoon ry.

Mattson, Greggor. 2014. “Nation-State Science: Lappology and Sweden's Ethnoracial Purity.” Comparative Studies in Society and History 56 (2): 320-350.

Ministry of Education and Culture (Finland). 2018. "Steering, Financing and Agreements of Higher Education Institutions, Science Agencies and Research Institutes.” Online article published October 1. Accessed January 5, 2019.

https://minedu.fi/en/steering-financing-and-agreements.

Mustonen, Tero. 2012. “Kohti saamelaistutkimuksen uutta tulkintakehystä.” In Saamenmaa: Kulttuuritieteellisiä näkökulmia, edited by Veli-Pekka Lehtola, Ulla Piela, and Hanna Snellman, 254-264. Helsinki: SKS.

Nyyssönen, Jukka, and Veli-Pekka Lehtola. 2017. "Introduction: From Depictions of Race to Revitalizing a People: Aspects of Research on the Sámi in Finland and Norway." Arctic and North 27: 50-62.

O’Brien, Jean, and Robert Warrior. 2016. "Building a Professional Infrastructure for Critical Indigenous Studies." In Critical Indigenous Studies: Engagements in First World Locations, edited by Aileen Moreton-Robinson. A Kindle eBook. Tucson: University of Arizona Press.

Otnes, Per. 2006. "Retrospect on 'The Sami Nation'. Text, Context, Field, Symbolic Violence. Confessions of a Bordering Actor." Dieđut/Sámi Instituhtta 3: 127-155.

Pääkkönen, Erkki. 2008. Saamelainen etnisyys ja pohjoinen paikallisuus: saamelaisten etninen mobilisaatio ja paikallisperustainen vastaliike. Rovaniemi: University of Lapland Press.

Pember, Mary Annette. 2010. “Ethnic Fraud?” Diverse: Issues in Higher Education 23 (25): 20-23.

Pewewardy, Cornel. 2004. "So You Think You Hired an 'Indian' Faculty Member? The Ethnic Fraud Paradox in Higher Education." In Indigenizing the Academy, edited by Devon Mihesuah and Angela Wilson, 200-217. Lincoln: University of Nebraska Press.

Porsanger, Jelena. 2004. “An Essay About Indigenous Methodology.” Nordlit 8: 105-120.

Prime Minister's Office (Finland). 2013. Finland's Strategy for the Arctic Region. Prime Minister's Office Publications. Accessed January 7, 2019.

https://vnk.fi/documents/10616/1093242/J1613_Finland's+Strategy+for+the+Arctic+Region.pdf/cf80d586-895a-4a328582-435f60400fd2?version=1.0. Prime Minister's Office (Finland). 2018-2019. Forest Lapp Culture and its Promotion" (Metsälappalainen kulttuuri ja sen edistäminen). Ongoing research project conducted by MDI and commissioned by the Finnish Prime Minster's Office. http://www.mdi.fi/kulta-hanke/.

Reflections on the Daniels Decision. 2018. “A Featured Section of Topia.” Canadian Journal of Cultural Studies 36: 7-55.

Sarivaara, Erika. 2012. Statuksettomat saamelaiset: paikantumisia saamelaisuuden rajoilla. Guovdageaidnu: Dieđut.

Sarivaara, Erika, Kaarina Määttä, and Satu Uusiautti, eds. 2013. Kuka on saamelainen ja mitä on saamelaisuus? Saamelaisuuden juurilla. Rovaniemi: University of Lapland Press.

Seurujärvi-Kari, Irja. 2012. “Ale Jaskkot Eatnigiella: Alkuperäiskansaliikkeen ja saamen kielen merkitys saamelaisten identiteetille." Phd Diss., University of Helsinki. 
Shore, Cris, and Susan Wright. 2017. "Introduction." In Death of the Public University? Uncertain Futures for Higher Education in the Knowledge Economy, edited by Cris Shore and Susan Wright, 1-30. New York: Berghahn Books.

Sámi Instituhtta. 2005. Sami Instituhtta - 30 jagi. Raporta Sámi Institutta 30-jagi ávvudeamis 28.10.2004. Guovdageaidnu: Sámi Instituhtta.

Stordahl, Vigdis. 1987. “The Difficult, But Challenging, Complexity of Contemporary Saami Reality - Comments on Robert Paine's Article 'Trails of Saami Self-Consciousness'." Anthropologica 29 (2): 189-194.

Stordahl, Vigdis. 2008. "Nation-Building through Knowledge Building: The Discourse of Sami Higher Education and Research in Norway." In Indigenous Peoples: Self-Determination, Knowledge, Identity, edited by Henry Minde, 249-265. Delft: Eburon.

Sturm, Circe. 2010. Becoming Indian: The Struggle Over Cherokee Identity in the Twenty-First Century. Santa Fe: School of Advanced Research Press.

Thuen, Trond. 1995. Quest for Equity: Norway and the Sami Challenge. St. Johns: Institute of Social and Economic Research, Memorial University of Newfoundland.

Toivanen, Reetta. 2016. "Localising the Global in the Superdiverse Municipalities of the Arctic: The Case of Inari." In Linguistic Genocide or Superdiversity? New and Old Language Diversities, edited by Reetta Toivanen and Janne Saarikivi, 221-246.

Bristol: Multilingual Matters.

Tuck, Eve, and Wayne Yang. 2012. “Decolonization is not a Metaphor.” Decolonization: Indigeneity, Education, Society 1 (1): $1-40$.

Valkonen, Sanna, Sami Kotiranta, and Saara Tervaniemi. 2018. “Alkuperäiskansaan kuuluminen identiteettivalintana? Uusidentifikaatiot ja -heimoutuminen cherokee ja métis-kontekstissa." In Häiritsevä Yhteiskuntatutkimus, edited by Jarno Valkonen, 143-168. Rovaniemi: Lapland University Press. 